\title{
The Growth of Milkfish (Chanos chanos Forsskål, 1775) Larvae from Several Hatcheries for Productivity Support for Development Culture in The Pond
}

\author{
Tony Setia Dharma, Gigih Setia Wibawa, AA Ketut Alit and Titiek Aslianti \\ Research institute of marine aquaculture and fisheries extension \\ Email: tonysetiadharma@gmail.com \\ Pos 140 Singaraja 81101
}

Received: 26 February 2020; Accepted: 13 April 2020

\begin{abstract}
Tony Setia Dharma, Gigih Setia Wibawa, AA Ketut Alit and Titiek Aslianti. 2020. The Growth of Milkfish (Chanos chanos Forsskål, 1775) Larvae from Several Hatcheries for Productivity Support for Development Culture in The Pond. Aquacultura Indonesiana, 21 (1): 8-13. This study aims to obtain information about the growth of second-generation milkfish fries (G2), HSS fries and wild fries that were farmed in hapa net. The study was conducted using hapa net with a volume of $1 \mathrm{~m}^{3}$ in a pond. The larvae used in this study were from G2 Small schale hatchery (HSS) and and wild fry with a total length (TL) about 1.5-2.0 $\mathrm{cm}$. The larvae were stocked with a density of 250 individuals $/ \mathrm{m}^{3}$. The study was conducted for three months until the larvae reached fingerling size with total length (TL) around 10.0-12.0 cm. The treatments were (A) G2 of larvae, (B) HSS of larvae and (C) wild of larvae. The research was carried out using Randomize Completely Design (RCD), and each treatment was repeated three times. The observed of growth for leng and weight every two weeks. The feed provided was commercial feed in the form of pellets with a protein content of $28-30 \%$, delivered two time in the morning and evening with a dose of 5-8\% biomass/days. The results showed that the fish of G2 milkfish test analysis were different significant $(\mathrm{P}<0.05)$, produced better survival rate $(\mathrm{SR})$ and growth (GR) in the amount of 20-25\% when compared to seeds from HSS (B) and did not different significant $(\mathrm{P}>0.05)$ from wild seeds $(\mathrm{C})$. The best of survival rate and growth produced was treatment at from of $\mathrm{G} 2$ fry were $90.20 \pm 2.60 \%$, total length of $12.80 \pm 2.40 \mathrm{~cm}$ and weight of $35.20 \pm 2.70 \mathrm{~g}$. Performance of seed produced from each treatment consists of 4 sizes, they are large (size A), medium (size B), small (size C) and very small (size D) with an average percentage of A) $25.10 \%, 67.10 \%, 5.20 \%$ and $2.60 \%$, B) $17.50 \%, 69.30 \%$ and $9.10 \%, 4.10 \%$ and C) $21.50 \%, 71.40 \%, 8.10 \%$ and $3.80 \%$.
\end{abstract}

Keywords: growth, ponds, milkfish G-2, HSS and wild fry

\section{Introduction}

Indonesia is the largest milkfish (Chanos chanos) producer in the world, followed by the Philippines (FAO, 2012). Milkfish is one of the important economic commodities for aquaculture, and has been determined by the Minister of Maritime Affairs and Fisheries in addition to being an industrialization program commodity, as well as a commodity for food security. The increase milkfish production is quite large, because Indonesia has a large area of aquaculture, which is spread mainly on the north coast of Java, Sumatra, Kalimantan and South Sulawesi. Even though milkfish seeds are currently difficult to obtain from nature, milkfish seeds from hatcheries can be produced in quite large quantities, especially on the north coast of Buleleng and Situbondo districts. In fact, in certain seasons most of the best quality milkfish seedlings produced from hatcheries are exported to the Philippines. The development of milkfish Continuously business often experiences problems, because the seeds used by the farmers are not good quality seeds, so they often cause slow milkfish growth and low survival rate. In the milkfish culture development continuously business in ponds, the quality of the seed is a critical success factor, in addition to other important factors such as cultivation of cultivation land, availability of feed and pest control. To get good quality milkfish seeds, the Indonesian Center for Marine Develop Research and Extension and Fisheries has tested milkfish seed quality through seed selection based on seed performance, 
including seed length size, swimming agility and seed response (Sudradjat. A., 2011 and Setiadharma, et al., 2014). Test results on community ponds dissemination activity in 2012 showed that milkfish continuously using selected seeds can increase production almost twice and shorten the maintenance period by about 2 months compared to milkfish continuous business using seeds without going through selection. Furthermore, in 2015 the G1 milkfish broodstock from the selection results have spawned and G-2 seeds have been produced with fast-growing character. (Anonim, 2010; 2016 and 2018) The milkfish G-2 produced has a fast growing performance and good diversity. Maritime Research and Development Agency as the only work unit that conducts research and development at the Ministry of Maritime Affairs and Fisheries is required to be able to produce technology that supports the development of aquaculture in the aquaculture sector. Several work units within the scope of the Maritime and Fisheries Research and Development Agency have produced a number of unit technology that can be applied directly to the community. In order to increase the effectiveness of the mission of disseminating $\mathrm{R} \& \mathrm{D}$ results, the Maritime and Fisheries Research and Development Agency implements the application of Science and Technology, as an effort to encourage the adoption and dissemination of research results to the fish farmers. The problem that has been encountered lately in milkfish develops the declining quality of seeds in the fish farmers. The application of milkfish continous develop can be expected to increase milkfish productivity through seed selection. In addition, there was also an increase in stocking densities and fermentation feeding in enlargement activities. It is expected that the application of the results of research and development can be something that is effective, so that the impact on increasing the income of fishing, coastal, and develop of fish farmers can be achieved to the maximum. The purpose of this study was to determine the growth of milkfish seed generation 2 (G2),
HSS and wild fry that are maintained in a controlled in the pond on ponds to support the application of milkfish science and technology in the fish farmers in the pond. The target of this research activity is to increase the income of milkfish farmers and the economy of the community in the coastal area.

\section{Materials and Method}

The study was conducted in a pond using a nine hapa size $1 \times 1 \times 1 \mathrm{~m}$. The treatment in this study used seeds size $1.5-2 \mathrm{~cm}$ with a stocking density of $250 \mathrm{pc} / \mathrm{m}^{2}$. The treatments in this research activity were (A) G2 seed, (B) Small scale hatchery (HSS) seed and (C) Natural seed. The research was carried out using Randomize Completely Design (RCD), and each treatment was repeated three times. The observed of growth for leng and weight every two weeks.. The feed provided was commercial feed in the form of pellets with a protein content of $28-30 \%$, delivered two time in the morning and evening with a dose of $5-8 \%$ biomass/days. The study was conducted for 3 months until the seeds reached the size of $10-12 \mathrm{~cm}$. The parameters observed were survival, growth, diversity and quality of seeds, as well as water quality ( temperature, oxygen, salinity, $\mathrm{pH}$ ).

\section{Result and Discussion}

The results showed that the fish of G2 seed milkfish and HSS test analysis were different significant $(\mathrm{P}<0.05)$, produced better survival rate (SR) and growth (GR) when compared to seeds from HSS (B) and did not different significant $(\mathrm{P}>0.05)$ from wild seeds $(\mathrm{C})$. The best of survival rate and growth produced was treatment at from of G2 fry were $90.20 \pm 2.60 \%$, total length of $12.80 \pm$ $2.40 \mathrm{~cm}$ and weight of $35.20 \pm 2.70 \mathrm{~g}$. Performance of seed produced from each treatment consists of 4 sizes, they are large (size A), medium (size B), small (size C) and very small (size D) with an average percentage of A) $25.10 \%, 67.10 \%, 5.20 \%$ and $2.60 \%, \mathrm{~B}) 17.50 \%, 69.30 \%$ and $9.10 \%, 4.10 \%$ and C) $21.50 \%, 71.40 \%, 8.10 \%$ and $3.80 \%$. Table 1 and 2. 
Table1. The result of survival rate, length and weigth of milkfish nursery in the pond at the end experiment

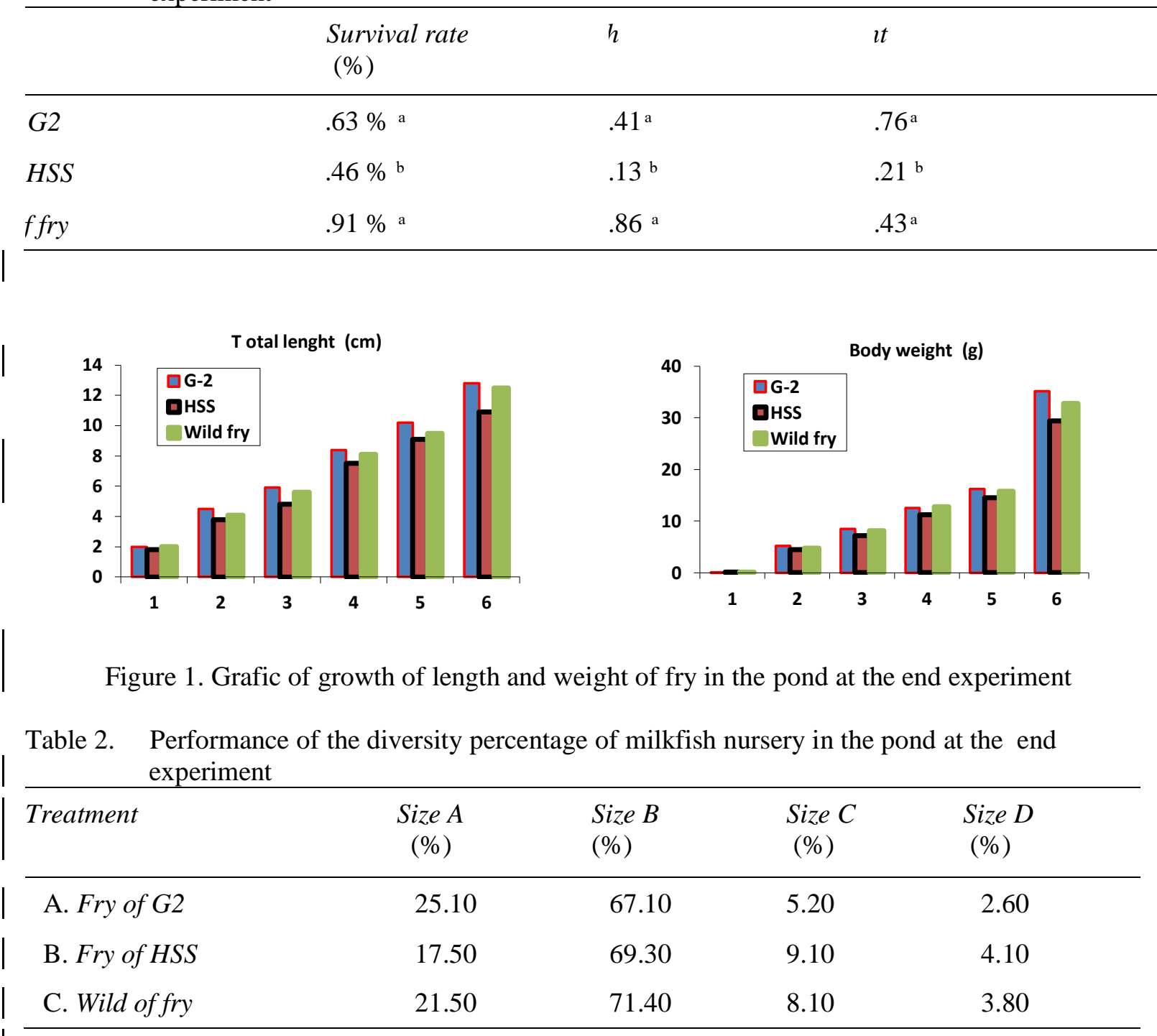

Table 3. The results of observations on the range of water quality of the nursery in the pond at the and experiment.

\begin{tabular}{lccc}
\hline Parameters & (Fry of G2) & (Fry of HSS) & (Wild of fry) \\
\hline Temperature $\left({ }^{\circ} \mathrm{C}\right)$ & $28.30-34.50$ & $27.50-33.80$ & $28.20-34.20$ \\
Salinity $($ ppt $)$ & $36.0-42.0$ & $36.0-41.0$ & $35.0-42.0$ \\
PH & $8.50-8.58$ & $7.80-8.56$ & $8.60-8.52$ \\
Oxigen $($ ppm $)$ & $4.48-5.96$ & $4.45-5.90$ & $4.46-5.92$ \\
\hline
\end{tabular}

Table 1 shows that the milkfish seeds of G-2 produce better survival rate (SR) and growth (GR) when compared to seeds from small scale hatchery (HSS) (B) and not different from natural origin seeds (C). Survival rate and growth produced were 90,26 $\pm 2,63 \%$, total length of $12,86 \pm 2,41 \mathrm{~cm}$ and weight of $35,23 \pm 2,76 \mathrm{~g}$, then diversity consisted of 4 seed size groups were large $(\operatorname{grad} A)$, medium $(\operatorname{grad} B)$, small $(\operatorname{grad} C)$ and very small (grad D) with an average percentage of diversity_25.10\%, $67.10 \%$, $5.20 \%$ and $2.60 \%$. Where it is known that milkfish can live and grow well with a diversity of diversity consisting of 4 sizes, of which the smallest size has the lowest percentage. It is suspected that maintenance techniques in hafa and feeding in the form of commercial pellets and pond environmental conditions are adequate. The according to 
Effendie (1978 or 1979) and Wibhawa (1992) , that competition is an attempt to get something in common or to get a measurement of each of the inventories of something that is actually potentially limited. When the amount of seed is too dense at the same space ratio, competition can occur, in this case the competition is more on oxygen uptake or environmental conditions so that such conditions can interfention of growth. pond / hafa or in the tank, so to reach the log size will require a faster maintenance time. In addition to the above, G2 seeds are seeds obtained from the spawning results of the G1 broodstock where the broodstock $\mathrm{G} 1$ is the individual selection results that have the character growing fast (Anonym, 2010; 2015). Season conditions can also be influential, during this year there is a lot more drought than during the rainy season, so the temperature in the medium of raising fish tends to increase which is around 27.50 to $34.50{ }^{\circ} \mathrm{C}$. Furthermore, water quality will be disrupted so that fertility for the growth of natural food (kelekap) does not develop. The provision of additional feed in the form of pellets in the nursery and milling is very important in intensive fish farming. The content of essential fatty acids in feed is very important, if the shortage will cause slow fish growth, decreased feed efficiency, and in some cases will lead to the death of fish seeds (Kompyang \& Ilyas.,1988). This can be seen at the appropriate density, that the growth and performance of the resulting seed is better, because the need for feed and the space rear tank of the seed is optimum. Kanazawa (1985), states that essential fatty acids (EPA and DHA) play an important role in the formation of components of the bodys tissue. It is expected to help the larvae and seeds in providing energy and the process of development phase can take place properly. The critical period of milkfish seeds in the nursery occurs from day 10-20, when the morphological changes occur and the response to feed increases. The nature of fish seeds tends to be very active and clustered on the surface when they will be fed. This requires a more specific pattern of handling, ware through food and environmental management (Setiadharma et al. 1993, 2006, 2013). Seeds require plankton and rotifer natural feed which is sufficiently available in the tub, because in the juvenile growth period still requires a type of natural food or (kelekap) so that the activity of the seeds is increased because of the presence of green water as a maintenance medium and the quality of the water media can increase. The range value is still well maintained because control is always carried out. Substitution of pond water needs to be done to prevent accumulation of over food which can disrupt the survival and growth of seeds. In fish rearing, temperature and DO water maintenance media around 28.30-34.50 ${ }^{\circ} \mathrm{C}$ and 4.48-5.96 ppm. Effendi (2003) states, that the DO value in ideal sea waters is around $\pm 7 \mathrm{mg} / \mathrm{L}$. The results of water quality observations during the study included, temperature, salinity, oxygen are still within the normal limits for the life of milkfish as seen in Table 3.

\section{Conclusion}

The results showed that, a better profile of milkfish seed growth in hafa in ponds was to use seeds from G-2, survival rate (SR) and growth (GR) produced were 90,26 \pm $2,63 \%$, total length $12,86 \pm 2,41 \mathrm{~cm}$ and weight $35,23 \pm 2,76 \mathrm{~g}$. Diversity consists of 4 seed sizes, were large ( $\operatorname{grad} \mathrm{A})$, medium (grad B), small ( $\operatorname{grad} C)$ and very small $(\operatorname{grad} D)$ with an average percentage of $25.10 \%$, $67.10 \%, 5.20 \%$ and $2.60 \%$. Nursery and seeding of fish seeds is very important to do in the ponds. Application of the stages of technology for the appropriate nursery business is expected to increase milkfish productivity and farmers' income in the community.

\section{Acknowledgements}

This research activity is funded by the Budget (APBN). The author would like to thank litigation technicians managing milkfish in tank and ponds, as well as to technicians in the Chemistry Lab and biology technicians who have assisted in research activities.

\section{References}

Ahmad, T., Erna R., dan M. Jamil R.Y. 1998. Buku Budidaya Bandeng Secara Intensif. Jakarta. PT Penebar Swadaya. 94-hlm .

Anonim. 2010. Protokol Pemuliaan Induk ikan Bandeng (Chanos chanos Forsskal). Standart Operasional Prosedur (SOP). Balai Besar Penelitian dan Pengembangan 
Budidaya Laut, Pusat Penelitian dan Pengembangan Perikanan Budidaya. Badan Penelitian dan Pengembangan Kelautan dan Perikanan. Kementerian Kelautan dan Perikanan. 15-hlm .

Anonim. 2015. Naskah Akademik. Rilis domestikasi ikan bandeng. Balai Besar Penelitian dan Pengembangan Budidaya laut. Puslitbangkan. Balitbang KP. 82 hlm.

Anonim. 2016. Teknologi Produksi Induk Unggul Bandeng Melalui Seleksi Individu. Rekomendasi Teknologi Kementerian Kelautan dan Perikanan. ISBN. Badan Penelitian dan Pengembangan Kelautan dan Perikanan. Kementerian Kelautan dan Perikanan. Hal 133-142.

Anonim. 2018. Keputusan Menteri Kelautan dan Perikanan Republik Indonesia Nomor 52/Kepmen-Kp /2018. Pelepasan Induk Bandeng Gondol sebaghi jenis ikan baru yang akan dibudidayakan, dengan deskripsi sebagaimana tercantum dalam Lampiran I dan gambar sebagaimana tercantum dalam lampiran II, yang merupakan bagian tidak terpisahkan dari Keputusan Menteri ini. Kementerian Kelautan dan Perikanan. 6hlm.

Arsyat H. dan S. Samsi. 1990. Budidaya ikan bandeng, Chanos chanos. INFIS manual Seri No. 11. Direktorat Jenderal Perikanan. 56 hal. Dalam Asmin Ismail, Manadiyanto dan Sindu Hermawan. 2005. Kajian usaha Bandeng umpan dan bandeng konsumsi pada tambak di Kamal. Jakarta Utara Prosiding Seminar Teknologi Perikanan Pantai. Bali. 6-7 Agustus 1998.

Boyd, C.E. 1990. Water Quality in Ponds for Aquaculture. Birmingham Publishing Co. Alabama : Auburn University.P : 482.P: 482.

Burhanuddin, S., dan T. Syarifuddin. 1993. Budidaya Ikan Bandeng, Chanos chanos, pada Padat Penebaran yang Berbeda Dalam Keramba Jaring Apung di Muara Sungai Lakawali, Kabupaten Luwa, Sulawesi Selatan. Jurnal Penelitian Budidaya Pantai, 9(3): 13-19.

Effendi, M.I.,1979. Metodologi Biologi Perikanan. Cetakan pertama. Yayasan Dewi Sri, Bogor: $112 \mathrm{p}$.

Effendi, H. 2003. Study of water quality for resource management and aquatic environments. Publisher Kanisius, Jogyakarta. $258 \mathrm{p}$.

FAO. 2012. The state of World fisheries And aquaculture 2012. Food And Agriculture Organization Of The United Nations Rome, 2012. FAO Fisheries and Aquaculture Department. 230 pages

Ismail, A., Manadiyanto dan Sindu H. 2005.
Kajian usaha bandeng umpan dan bandeng konsumsi pada tambak di Kamal. Jakarta Utara Prosiding Seminar Teknologi Perikanan Pantai. Bali. 6-7 Agustus 1998. Hal: 192-193.

Kanazawa. A.1985. Nutrition of Penaeid Prawn and Shrimp, p. 121-130. In Y. Taki, J. H. Primavera and J. A. Uobrera (Eds). Proceedings of The First International Conference on The Culture of Penaeid Prawn/Shrimp Aquaculture. Dept., SEAFDEC, Illoilo, Philippines.

Kompyang, I.P., dan Ilyas. 1988. Nutrisi Ikan/Udang Relevansi untuk larva/Induk. Prosiding Seminar Nasional Pembenihan Ikan dan Udang. Prosiding Puslitbangkan No. 13/1988.Kerjasama Badan Penelitian dan Pengembangan Pertanian dan Universitas Padjajaran. Hal 248-290.

Priyono, A., Taufik A. dan Toni S. 1993. Pengaruh penambahan nutrisi pakan terhadap perkembangan gonad induk bandeng, Chanos chanos Forsskal. J. Penelitian Budidaya Pantai 9 (1): 51-58.

Priyono, A., Titiek A., Tony S., dan I Nyoman A. G. 2011. Petunjuk Teknis Perbenihan Ikan Bandeng (Chanos chanos Forsskal). Balai Besar Penelitian dan Pengembangan Budidaya Laut. Badan Penelitian dan Pengembangan Kelautan dan Perikanan. Kementerian Kelautan dan Perikanan. ISBN: 978-979-17440-6-5. 45-hlm .

Rachmansyah dan Burhanudin, 1993. Prospek Pengembangan Budidaya Bandeng dalam Karamba Jaring Apung di Muara Sungai. Simposium Perikanan Indonesia I, Jakarta 25-27 Agustus 1993.

Rachmansyah, Syarifuddin T. dan Usman, 1997. Produksi Ikan Bandeng Super dalam Karamba Jaring Apung di Laut. Seminar Hasil-hasil Penelitian Berbasis Perikanan, Peternakan dan Sistem Usaha Tani di Kawasan Timur Indonesia, Kupang, 28-31 Juli 1997.

Setiadharma, T. 1993. Pengaruh padat penebaran terhadap kelangsungan hidup benih bandeng, Chanos chanos Forskal dalam hapa. J. Penelitian Budidaya Pantai 9 (1) Hal 99-104.

Setiadharma, T. dan Agus P., 1994. Pengangkutan gelondongan ikan bandeng, Chanos chanos pada kepadatan yang berbeda dengan sistem tertutup. J. Penelitian Budidaya Pantai 10 (1) Hal 95100.

Setiadharma,T., Agus P., Titiek A., Irwan S., Gigih S.W. 2012. Teknik Pendederan ikan Bandeng, Chanos chanos Forsskal). Makalah. Disampaikan dalam Acara Diseminasi dii Kabupaten Gresik Jawa 
The Growth of Milkfish (Chanos chanos Forsskål, 1775) Larvae from Several Hatcheries for Productivity Support for Development Culture in The Pond (Tony setia dharma et al.)

Timur pada tanggal 17 April 2012. 15 hlm .

Setiadharma, T., Iswari R. A., Septyan A, dan Endhay K. 2014. Pengembangan Budidaya Bandeng Melalui Penerapan Iptek dengan Benih Unggul Hasil Seleksi Di Kabupaten Kendal, Jawa tengah. Prosiding Forum Inovasi Teknologi Akuakultur 2014. Pusat Penelitian dan Pengembangan Perikanan Budidaya. Balitbang KP. KKP. ISBN 979-3692-64-7. Hal 73-81.

Sudradjat A. 2011. Panen Bandeng 50 Hari. Buku. Penebar Swadaya. Jakarta. 14hlm.

.Sudradjat, A., Wedjatmiko, dan Tony S. 2011. Budidaya Ikan Bandeng (Chanos chanos Forsskal). Balai Besar Penelitian dan Pengembangan Budidaya Laut. Badan Penelitian dan Pengembangan Kelautan dan Perikanan. Kementerian Kelautan dan Perikanan. ISBN: 978-979-786-038-7. 45 hlm.

Wibhawa, I.D.G.D. 1992. Pengaruh berbagai tingkat salinitas dan kepadatan telur yang berbeda terhadap daya tetas serta kelangsungan hidup prolarva bandeng (Chanos chanos Forskal). [Skripsi]. Jurusan Perikanan, Fakul-tas Pertanian, Universitas Warmadewa. Denpasar. 95 hlm. 